\title{
REDESCRIPTION OF EREMOBELBA GRACILIOR BERLESE, 1908 (ACARI, ORIBATIDA, EREMOBELBIDAE)
}

\author{
Sergey G. Ermilov
}

\author{
Tyumen State University, Tyumen, Russia \\ e-mail: ermilovacari@yandex.ru
}

ABSTRACT: The redescription of Eremobelba gracilior Berlese, 1908 (Oribatida, Eremobelbidae) is presented, based on the material collected in Washington D.C. and Columbia, Missouri (USA). Main morphological traits of this species are summarized.

KEY WORDS: Oribatid mite, Eremobelba, systematics, morphology, redescription, USA.

DOI: 10.21684/0132-8077-2021-29-2-147-153

\section{INTRODUCTION}

The oribatid mite Eremobelba gracilior (Acari, Oribatida, Eremobelbidae) was described by Berlese (1908) from two rather distant places in the USA: Washington D.C. and Columbia, Missouri. Norton and Kethley (1990) selected a lectotype from the Washington population. It is by far the most common Eremobelba species in the eastern USA, but it has never been redescribed in detail. The original and supplementary descriptions (Berlese 1908, 1910; Banks 1947) of E. gracilior are incomplete, brief and poorly illustrated, and they do not allow the readers to clearly understand the morphology of this species. The main goal of this paper is to present the redescription of this species on the basis of the topotypes, and to summarize the main morphological traits, which will help with the identification of E. gracilior in the future.

\section{MATERIALS AND METHODS}

Specimens. Specimens (all adults) of E. gracilior were received from Prof. Dr. Roy A. Norton (personal collection): (1) twelve topotypes: USA, Washington, D. C., Glover Archbold Park, no habitat data, January 22, 1967 (W. S. Suter); (2) five specimens: Missouri, Boone County, Columbia, Hinkson Creek, the University of Missouri campus, moss on soil, April 24, 1985 (J.B. Kethley and R. A. Norton).

Observation and documentation. Specimens were mounted in lactic acid on temporary cavity slides for measurement and illustration. Body length was measured in lateral view, from the tip of the rostrum to the posterior edge of the gastronotum. Notogastral width refers to the maximum width of the notogaster in dorsal view. Lengths of body setae were measured in lateral aspect. All body measurements are presented in micrometers $(\mu \mathrm{m})$. Formulas for leg setation are given in paren- theses according to the sequence trochanter-femur-genu-tibia-tarsus (famulus included). Formulas for leg solenidia are given in square brackets according to the sequence genu-tibia-tarsus. Drawings were made with a camera lucida using a Leica transmission light microscope "Leica DM 2500". SEM micrographs were made with the aid of a JEOL-JSM-6510LV SEM microscope.

Terminology. General morphological terminology used in this paper mostly follows that of F. Grandjean: see Travé and Vachon (1975) for references, Norton (1977) for leg setal nomenclature, and Norton and Behan-Pelletier (2009) for overview.

Abbreviations. Prodorsum: cos-costula; $m t$-mediobasal tubercle; st-sejugal tubercle; lt -lateral tubercle; ro, le, in, $b s$, ex - rostral, lamellar, interlamellar, bothridial and exobothridial seta, respectively. Notogaster: $c r$ - crista; $c, l a, l m, l p$, $h, p$ - setae; ia, im, ip, ih, ips-lyrifissures; glaopisthonotal gland opening. Gnathosoma: $a, m$, $h$-subcapitular setae; or - adoral seta; $d, l$, sup, inf, cm, ul, sul, vt, lt - palp setae; $\omega$ - palp solenidion; as - axillary saccule; cha, chb-cheliceral setae; $T g$ - Trägårdh's organ. Epimeral and lateral podosomal regions: $1 a-c, 2 a, 3 a-c, 4 a-c$ - epimeral setae; $V a$-ventrosejugal tubercle; $P d I, P d I I-$ pedotectum I, II, respectively; dis-discidium. Anogenital region: $g$, an-genital and anal setae, respectively; iad - adanal lyrifissure; po - preanal organ. Legs: $\mathrm{Tr}, \mathrm{Fe}, \mathrm{Ge}, \mathrm{Ti}, \mathrm{Ta}$-leg trochanter, femur, genu, tibia, tarsus, respectively; $s a c$ - saccule; $\omega, \varphi, \sigma$-leg solenidia; $\varepsilon$-leg famulus.

\section{REDESCRIPTION}

\section{Eremobelba gracilior Berlese, 1908}

(Figs. 1-20)

Measurements. Body length: 381-448 (17 specimens); notogaster width: 215-256 (17 specimens). 


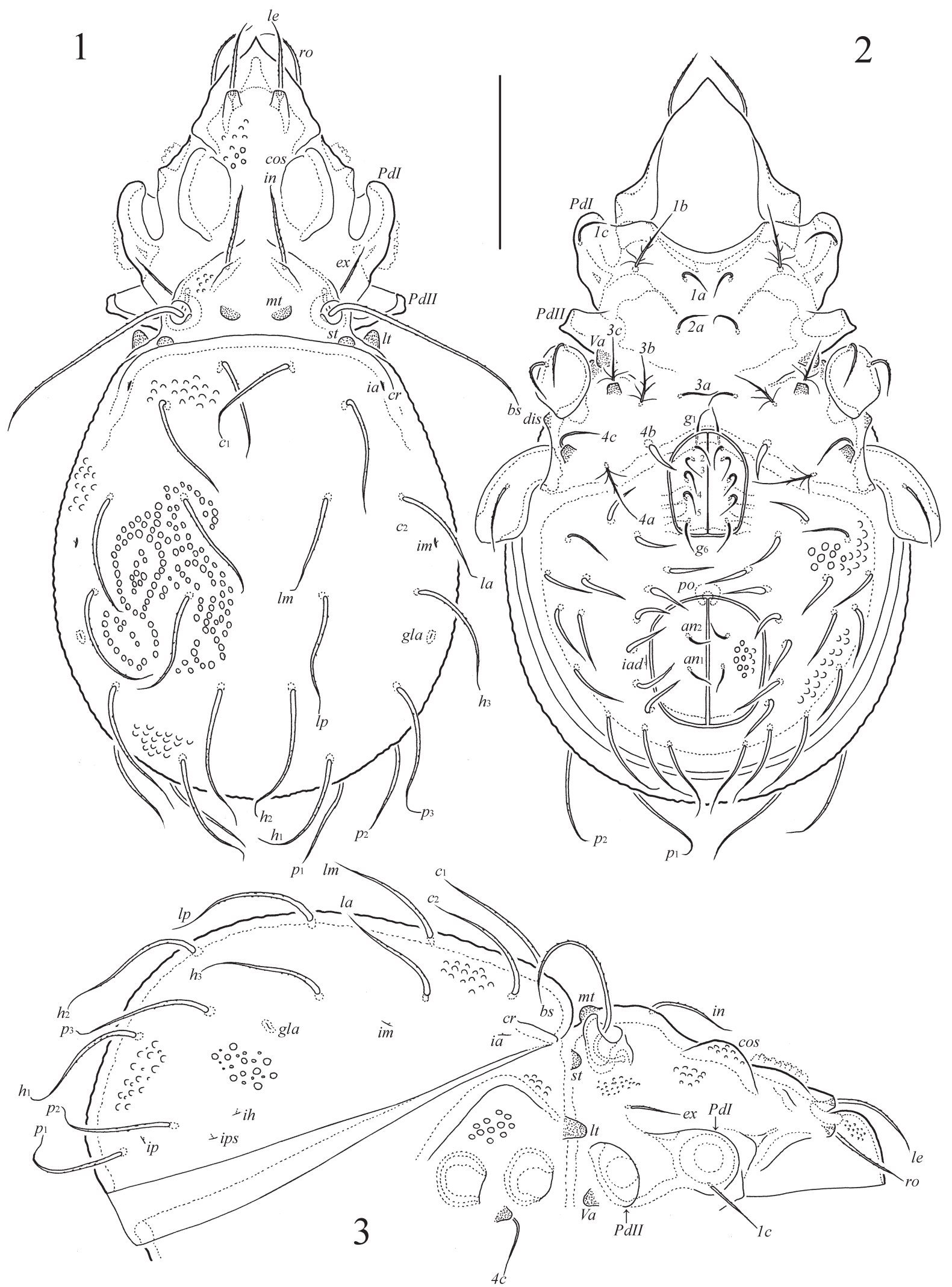

Figs. 1-3. Eremobelba gracilior Berlese, 1908, adult: 1-dorsal view; 2-ventral view (gnathosoma and legs except trochanters III, IV omitted); 3 - lateral view (gnathosoma, legs and ventral plate omitted). Scale bar=100 $\mu \mathrm{m}$. 


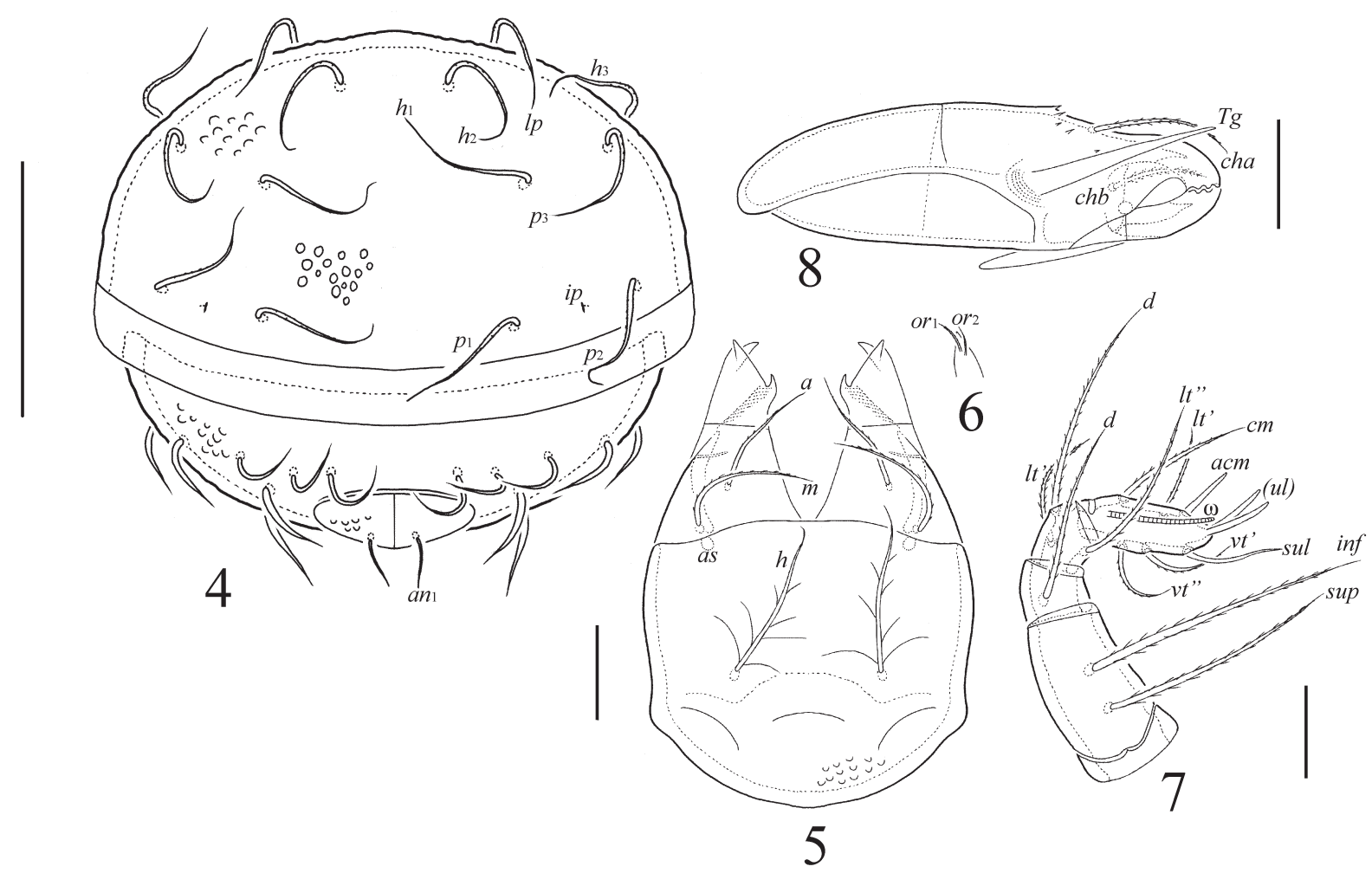

Figs. 4-8. Eremobelba gracilior Berlese, 1908, adult: 4-posterior view; 5-subcapitulum, ventral view; 6-left lip with adoral setae, ventral view; 7 -palp, right, antiaxial view; 8 -chelicera, left, paraxial view. Scale bars $=100 \mu \mathrm{m}$ (4), $20 \mu \mathrm{m}(5,6,8), 10 \mu \mathrm{m}(7)$.

Integument. Body color brown. Body and legs covered by gel-like and densely tuberculate (diameter of tubercle up to 4) cerotegument. Distinct tuberculate polygonal ornamentation on notogaster absent (except some dorsal parts with unclear ornamentation).

Prodorsum. Rostrum triangular. Costula slightly developed. Interbothridial region with one pair of mediobasal tubercles. Rostral, lamellar and interlamellar setae approximately similar in length (45-49), setiform, barbed; ro inserted of small tubercle, le on quadrangular tubercle, in on diagonal ridge. Exobothridial seta (28-32) setiform, thin, barbed. Bothridial seta (131-147) setiform, barbed.

Notogaster. One pair of humeral cristae slightly developed. One pair of sejugal tubercles present. Eleven pairs of notogastral setae $\left(c_{1}, c_{2}, l a, l m, p_{1}\right.$, $p_{2}, 61-73$; others $\left.82-90\right)$ setiform, with flagellate tip, barbed.

Gnathosoma. Subcapitulum size: 98-102 × 69-73. Basal part of subcapitulum with three depressions. Subcapitular setae $a(28-32)$ and $m(28-32)$ setiform, barbed; $h(41-45)$ with ciliate branches. Adoral seta or $_{1}(8)$ setiform, slightly barbed; or $_{2}$ (6) setiform, smooth. Postpalpal seta (6) spiniform, slightly barbed. Axillary saccule present. Palp
(45-49) with setation $0-2-1-3-8(+\omega)$. Solenidion long, bacilliform, attached (except distal part) to the surface of tarsus. Chelicera (86-90) with setiform, barbed setae (cha, 24-26; chb, 16-18).

Lateral podosomal and epimeral regions. Lateral tubercle developed between and dorsal of acetabula II and III. Ventrosejugal tubercle $V a$ present. Epimeral setal formula: 3-1-3-3. Epimeral setae $1 b(41-45), 3 b, 3 c, 4 a(36-41)$ setiform, with ciliate branches; $4 b$ (32-36) narrowly phylliform, roughened; $1 a, 1 c, 2 a, 3 a(20-24), 4 c$ (32-36) setiform, roughened; $3 c$ and $4 c$ inserted on quadrangular tubercles.

Anogenital region. Six pairs of genital (20-24) and two pairs of anal (20-24) setae setiform, roughened. Aggenitoadanal region with 15-17 pairs of setae (number of setae located close to anal aperture varies from three to five); of these, three posterior pairs (32-36) setiform, with short flagellate tip, roughened, others (32-36) narrowly phylliform or thickened, roughened. Adanal lyrifissure located parallel and close to anal plate.

Legs. Claw of each leg strong, smooth. Femora I-IV and trochanters III, IV with three or four ventral sacculi. Formulas of leg setation and solenidia: I (1-5-4-4-20) [1-2-2], II (1-5-4-5-16) [1-1-2], 


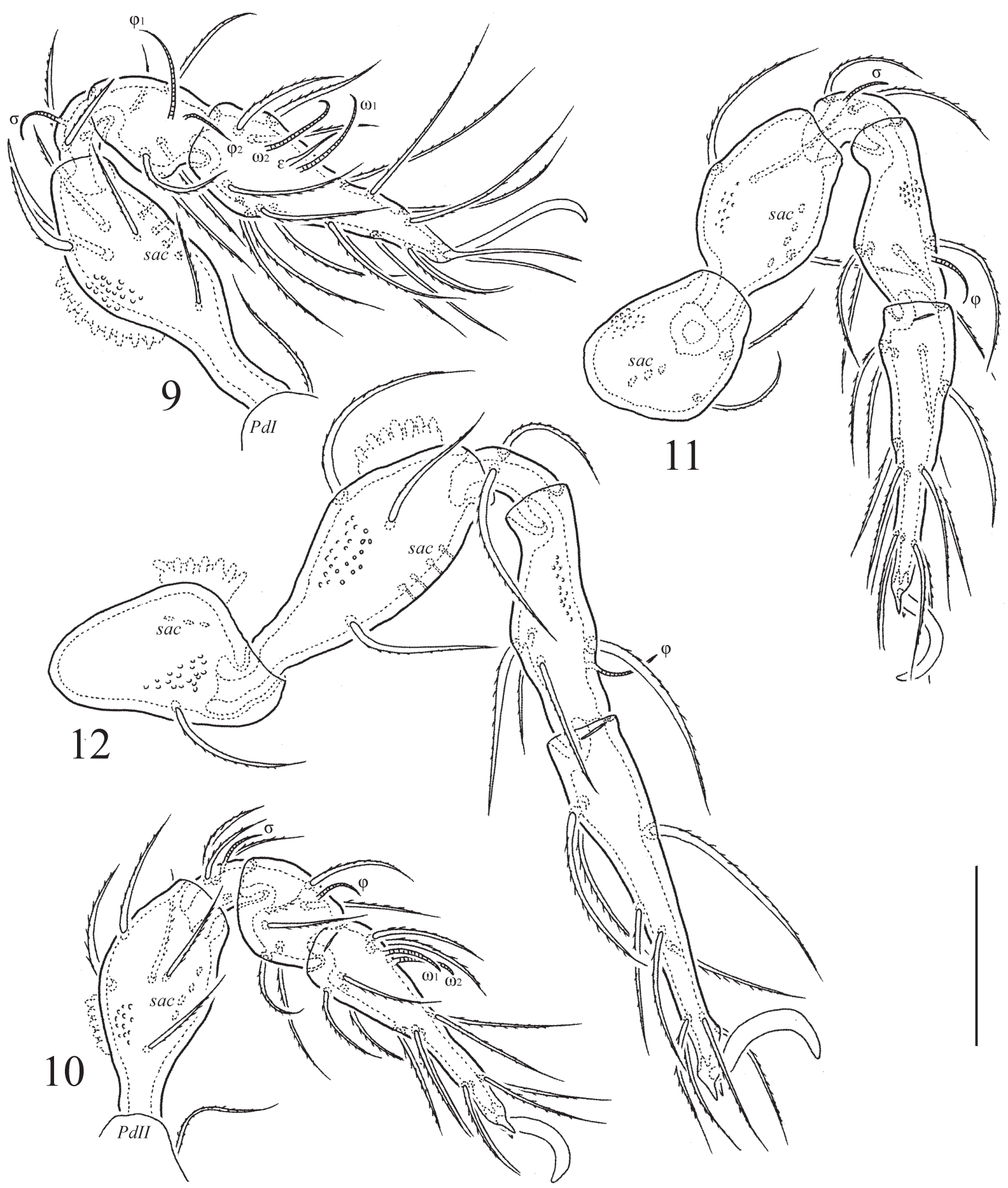

Figs. 9-12. Eremobelba gracilior Berlese, 1908, adult: 9-leg I (basal part is covered with pedotectum I), right, antiaxial view; 10 - - leg II (basal part is covered with pedotectum II), right, antiaxial view; 11-leg II, right, paraxial view; 12 -leg IV, left, antiaxial view. Scale bar $=50 \mu \mathrm{m}$.

III (2-3-2-4-15) [1-1-0], IV (1-3-2-4-12) [0-1-0]; homology of setae and solenidia are indicated in Table 1. All solenidia thickened, slightly curved, rounded apically. Famulus of tarsus I setiform, erect.

Remarks. Based on our redescription and on the available data (Berlese 1908, 1910; Banks 1947 ) of adult E. gracilior, we propose the fol- lowing diagnostic morphological traits for this species: body size: $381-448 \times 215-256$; body covered by tuberculate cerotegument (distinct tuberculate polygonal ornamentation on notogaster absent); rostrum triangular; interbothridial and sejugal tubercles present; rostral, lamellar and interlamellar setae long, setiform, barbed; noto- 

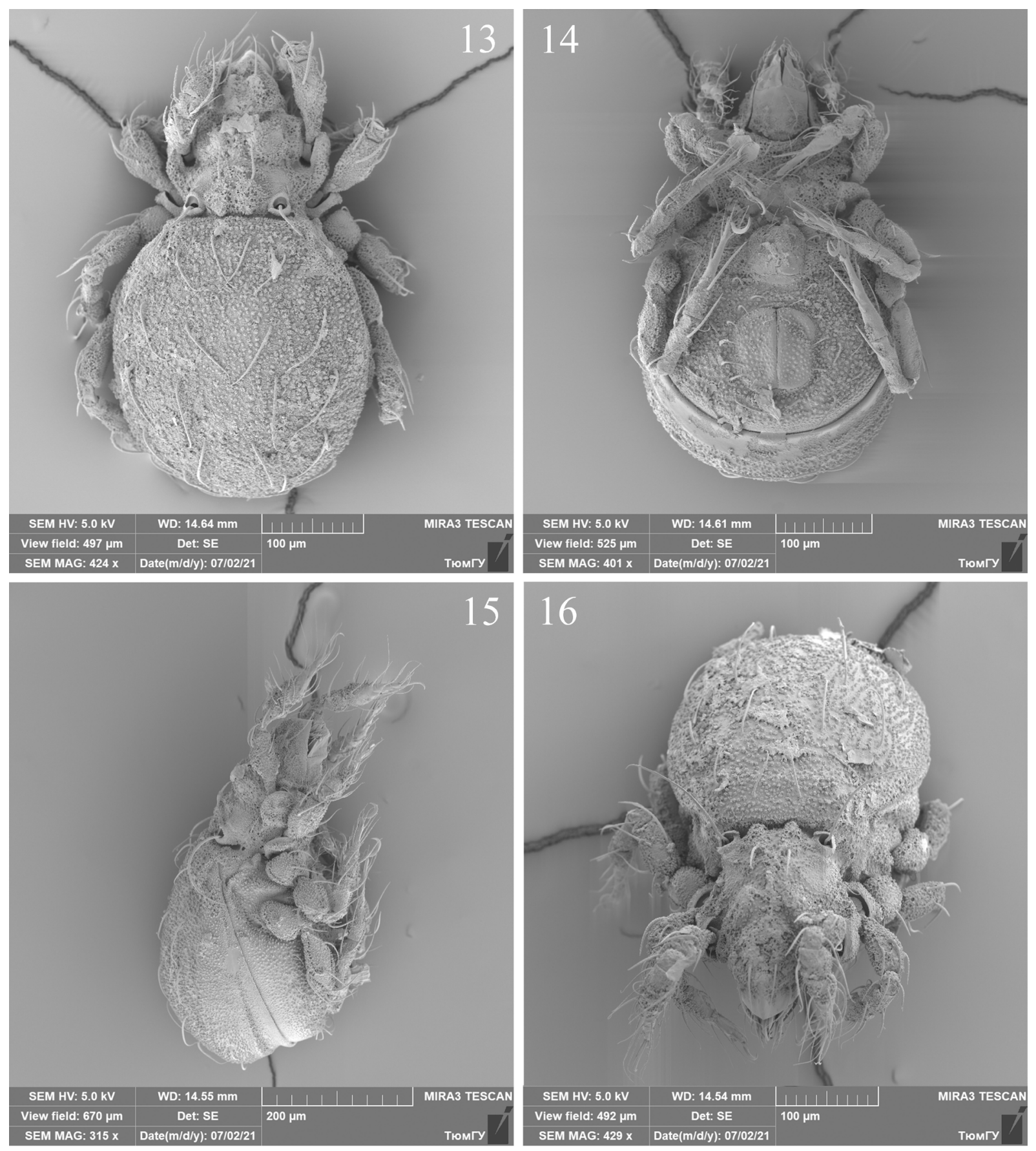

Figs. 13-16. Eremobelba gracilior Berlese, 1908, adult, SEM micrographs: 1-dorsal view; 2-ventral view; 3-lateral view; 4 -dorsoanterior view.

gastral setae long, setiform, with flagellate tip, barbed; lateral podosomal and ventrosejugal tubercle Va present; epimeral setae $1 b, 3 b, 3 c, 4 a$ setiform, with ciliate branches, $4 b$ narrowly phylliform, roughened, others setiform, roughened, $3 c$ and $4 c$ inserted on quadrangular tubercles; genital and anal setae setiform, roughened; aggenitoadanal region with $15-17$ pairs of setae (three posterior pairs longest, setiform, with short flagellate tip, roughened, others narrowly phylliform or thickened, roughened).

\section{ACKNOWLEDGEMENTS}

I cordially thank Prof. Dr. R.A. Norton (State University of New York, College of Environmental Science and Forestry, Syracuse, USA) for loaning the material of Eremobelba gracilior Berlese, 1908 from his personal collection. We also thank A.A. Gu- 

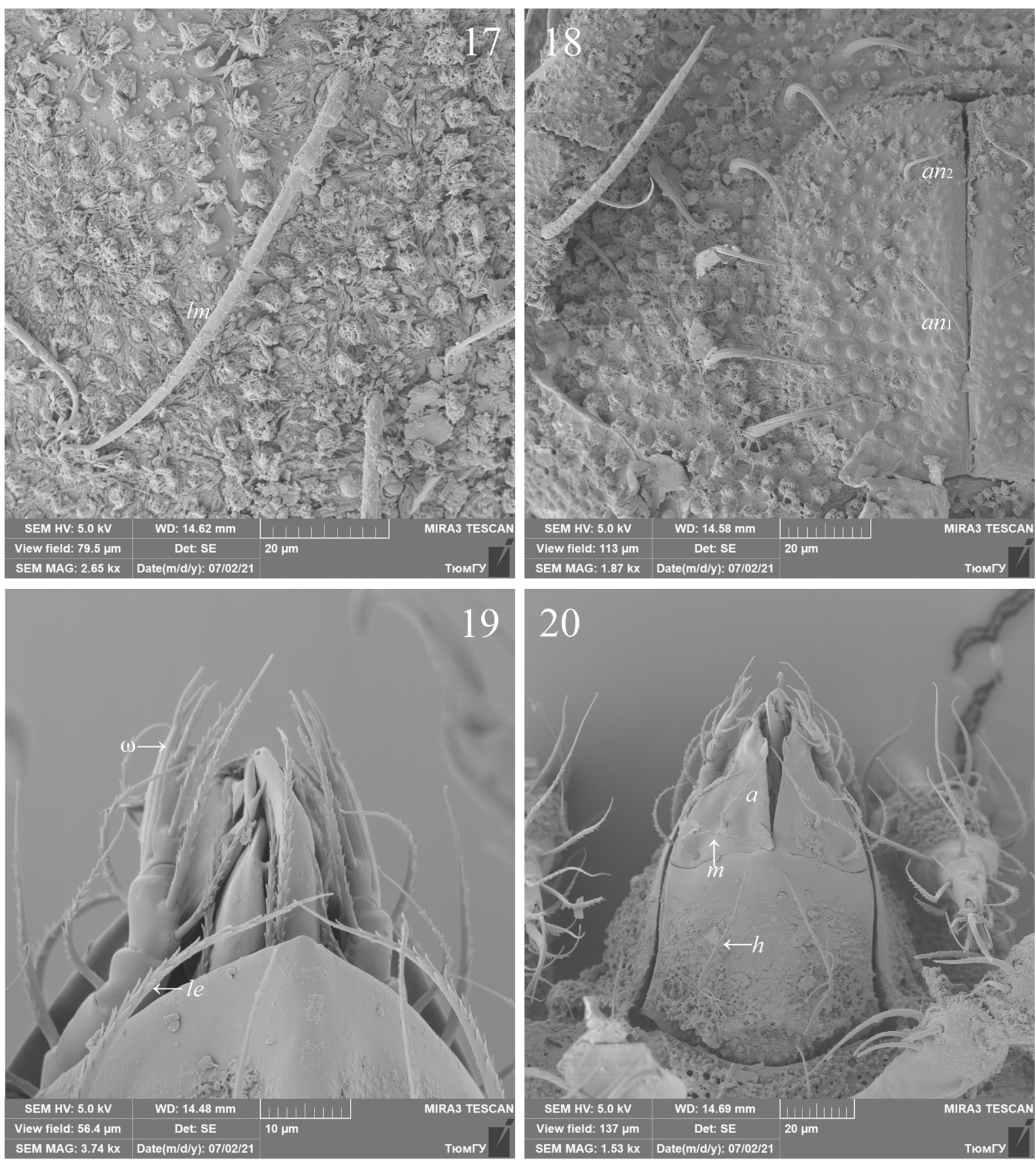

Figs. 17-20. Eremobelba gracilior Berlese, 1908, adult, SEM micrographs: 17—part of dorsal notogaster; 18 — part of anoadanal region; 19-rostrum and subcapitulum, dorsoanterior view; 20 - subcapitulum, ventral view.

bin (Tyumen State University, Tyumen, Russia) for SEM micrographs.

This research was supported by the cooperative agreement No. FEWZ-2021-0004 from the Russian Ministry of Science and Higher Education.

\section{REFERENCES}

Banks, N. 1947. On some Acarina from North Carolina. Psyche, 54: 110-141.
Berlese, A. 1908. Elenco di generi e specie nuove di Acari. Redia, 5: 1-15.

Berlese, A. 1910. Acari nuovi. Manipulus V-VI. Redia, 6: 199-234.

Norton, R.A. 1977. A review of F. Grandjean's system of leg chaetotaxy in the Oribatei (Acari) and its application to the family Damaeidae. In: D.L. Dindal (Ed.). Biology of Oribatid Mites. SUNY College of Environmental Science and Forestry, Syracuse, pp. 33-61. 
Norton, R.A. and Behan-Pelletier, V.M. 2009. Suborder Oribatida. Chapter 15. In: G.W. Krantz and D.E. Walter (Eds.). A Manual of Acarology. Texas Tech University Press, Lubbock, pp. 430-564.

Norton, R.A. and Kethley, J.B. 1990. Berlese's North American oribatid mites: historical notes, recom- binations, synonymies and type designations. $R e$ dia, 62(2): 421-499.

Travé, J. and Vachon, M. 1975. François Grandjean. 1882-1975 (Notice biographique et bibliographique). Acarologia, 17(1): 1-19.

Table 1

Leg setation and solenidia of adult Eremobelba gracilior Berlese, 1908.

\begin{tabular}{|l|l|l|l|l|l|}
\hline Leg & Tr & $F e$ & $G e$ & $T i$ & $T a$ \\
\hline I & $v^{\prime}$ & $d,(l), b v^{\prime}, v^{\prime}$ & $d,(l), v^{\prime}, \sigma$ & $(l),(v), \varphi_{1}, \varphi_{2}$ & $(f t),(t c),(i t),(p),(u),(a), s,(p v),(p l), l^{\prime}, v^{\prime}, \varepsilon, \omega_{1}, \omega_{2}$ \\
\hline II & $v^{\prime}$ & $d,(l), b v^{\prime}, v^{\prime}$ & $d,(l), v^{\prime}, \sigma$ & $d,(l),(v), \varphi$ & $(f t),(t c),(i t),(p),(u),(a), s,(p v), l^{\prime}, \omega_{1}, \omega_{2}$ \\
\hline III & $l^{\prime}, v^{\prime}$ & $d, l^{\prime}, e v^{\prime}$ & $d, l^{\prime}, \sigma$ & $d, l^{\prime},(v), \varphi$ & $(f t),(t c),(i t),(p),(u),(a), s,(p v)$ \\
\hline IV & $v^{\prime}$ & $d, l^{\prime}, e v^{\prime}$ & $d, l^{\prime}$ & $d, l^{\prime},(v), \varphi$ & $f t^{\prime},(t c),(p),(u),(a), s,(p v)$ \\
\hline
\end{tabular}

Note: Roman letters refer to normal setae, Greek letters — to solenidia (except $\varepsilon$ —famulus), Single quotation mark (') designates setae on the anterior and double quotation (") - setae on the posterior side of a given leg segment. Parentheses refer to a pair of setae. 